\title{
An Archival Search for the Alamo-Concepcion Aquaduct
}

\author{
I. Waynne Cox \\ Center for Archaeological Research
}

Follow this and additional works at: https://scholarworks.sfasu.edu/ita

Part of the American Material Culture Commons, Archaeological Anthropology Commons, Environmental Studies Commons, Other American Studies Commons, Other Arts and Humanities Commons, Other History of Art, Architecture, and Archaeology Commons, and the United States History Commons

Tell us how this article helped you.

This Article is brought to you for free and open access by the Center for Regional Heritage Research at SFA ScholarWorks. It has been accepted for inclusion in Index of Texas Archaeology: Open Access Gray Literature from the Lone Star State by an authorized editor of SFA ScholarWorks. For more information, please contact cdsscholarworks@sfasu.edu. 
An Archival Search for the Alamo-Concepcion Aquaduct

Creative Commons License

(c) $($ ) $(9)$

This work is licensed under a Creative Commons Attribution-NonCommercial 4.0 International License 


\title{
AN ARCHIVAL SEARCH FOR THE ALAMO-CONCEPCIÓN AQUEDUCT
}

\author{
I. Waynne Cox
}

Robert J. Hard, Principal Investigator

${ }^{\circ}$ copyright

Center for Archaeological Research The University of Texas at San Antonio Archaeological Survey Report, No. 231 
The following information is provided in accordance with the General Rules of Practice and Procedure, Chapter 41.11 (Investigative Reports), Texas Antiquities Committee:

1. Type of investigation: Archival research

2. Project name: Alamo-Concepción Aqueduct

3. County: Bexar

4. Principal investigator: Robert J. Hard

5. Name and location of sponsoring agency: San Antonio Water System, P.O. Box 839966, San Antonio, Texas 78283

6. Texas Antiquities Committee Permit No.: n/a

7. Published by the Center for Archaeological Research, The University of Texas at San Antonio, San Antonio, Texas 78249-0658, 1995

A list of publications offered by the Center for Archaeological Research can be obtained by sending $\$ 1.00$ to the Center for Archaeological Research, The University of Texas at San Antonio, 6900 N. Loop 1604 West, San Antonio, Texas 78249-0658. 
ABSTRACT

\begin{abstract}
In June 1994, the Center for Archaeological Research of The University of Texas at San Antonio undertook an archival search for the San Antonio Water System to evaluate the impact of construction along South Alamo Street in downtown San Antonio. Previous research indicated the probable remains of a stone aqueduct below the street surface near the intersection of South Alamo and South St. Mary's streets.
\end{abstract}

The results of this study indicate that the historical structure may be imperiled by the construction; therefore, monitoring should be conducted during any excavation in that area. If any traces of the aqueduct are encountered, extensive archaeological investigation may be necessary. 


\section{CONTENTS}

ABSTRACT $\ldots \ldots \ldots \ldots \ldots \ldots \ldots \ldots \ldots \ldots \ldots \ldots \ldots \ldots \ldots \ldots \ldots \ldots \ldots$ FIGURES $\ldots \ldots \ldots \ldots \ldots \ldots \ldots \ldots \ldots \ldots \ldots \ldots \ldots \ldots \ldots \ldots \ldots$ ii

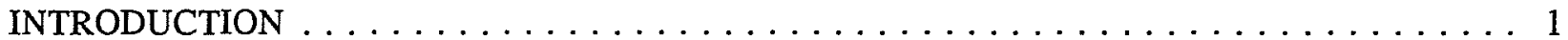

A BRIEF HISTORY OF THE ALAMO AND CONCEPCIÓN ACEQUIAS . . . . . . . . . . 2

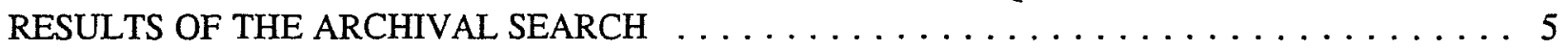

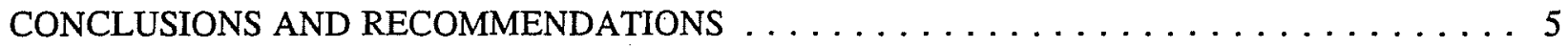

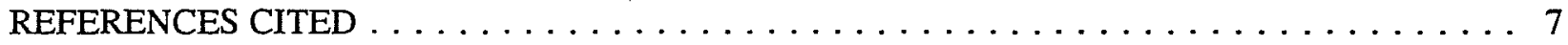

\section{FIGURES}

Figure 1. Location of the aqueduct. $\ldots \ldots \ldots \ldots \ldots \ldots \ldots \ldots \ldots \ldots \ldots \ldots$

Figure 2. Friesleben survey.. . . . . . . . . . . . . . . . 6 


\section{INTRODUCTION}

In June 1994, the San Antonio Water System requested that the Center for Archaeological Research (CAR) of The University of Texas at San Antonio conduct an archival search to evaluate the archaeological impact of work to be conducted along South Alamo Street in downtown San Antonio. Previous research (c.f. Corner 1890) had indicated that a substantial stone aqueduct had existed to convey the waters of the irrigation ditch, or acequia, of the Mission San Antonio de Valero (the Alamo) across the Concepción ditch near the intersection of South Alamo and South St. Mary's streets (Figure 1). The present study was undertaken to determine as nearly as possible the exact location of this buried historic structure prior to any disturbance by subterranean construction.

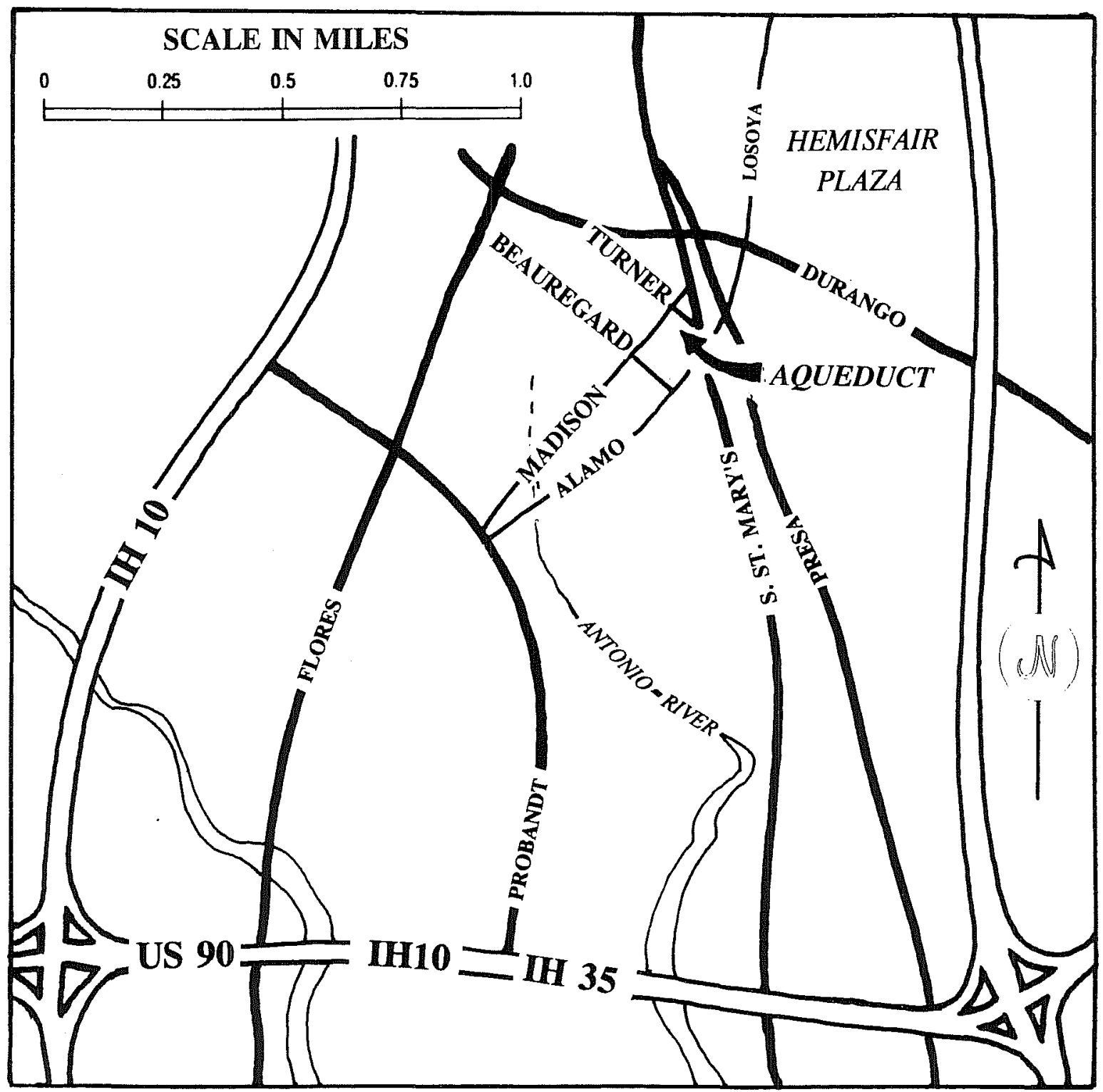

Figure 1. Location of the aqueduct. 


\section{A BRIEF HISTORY OF THE ALAMO AND CONCEPCIÓN ACEQUIAS}

On May 5, 1718, Governor Alarcón, "fixing the royal standard with the requisite solemnity" (Hoffman 1938:49), established the Villa de Bejar, named in honor of the brother of the Viceroy, near San Pedro Springs. He also gave orders to "begin with all assiduity the construction of canals for both the villa and the mission of San Antonio de Balero [sic]" (Hoffman 1938:49), thus initiating the San Antonio acequia system. Investigations shortly after their arrival had located an area on the ford of the San Antonio River, about one-half mile below the headwaters, where the " . . w water rises to the top of the ground, and the entire work is a matter of using a plow" (Hoffman 1938: 317-318). This point is just below the juncture of the numerous springs that join Olmos Creek to form the San Antonio River. When the mission was moved is not known, but during the first year Father Olivares suffered a fall from his horse and broke his leg; therefore, it is probable that the move was delayed until he recovered in the spring of 1719 (Habig 1968:41) Since the acequia was initiated in January of that year, it would have been constructed to serve the intended new site, near the Alameda (a promenade which now forms part of Commerce Street) to the south of its present location. This would mean that the Mission San Antonio de Valero acequia, later to be known as the Alamo Madre, was begun in 1719.

The acequia emanated from the ford of the Paso de Tejas, near the present crossing on Hildebrand Avenue, by means of a diversion dam that sprang from the west bank of the river and extended into the stream to raise and direct the flow toward the eastern bank where the canal intake was located. The acequia then traced a sinuous path: between the river and the low hills to the east, toward the south-southwest to pass through the mission grounds, to return to the river at the largest bend. The ditch was approximately 3.5 miles in length. Later additions to the channel, branching near the mission and irrigating additional labores or farm lands to the east and south, extended the total length of the acequia to approximately 10 miles.
On February 23, 1720, Lieutenant General Captain Juan Valdéz, accompanied by Father Margil and an official party, arrived at a site ". . . where water can be drained from the San Antonio River to irrigate the land" (Valdéz 1720:32) and ". . . went down river following the direction where the irrigation ditch is to be" (Valdéz 1720:23). They selected a site where "... the land offered such rich pastures and plentiful woods for beams, quarry stones, and firewood. There are excellent exits and entrances along the river for the cattle, sheep, goats and horses" (Valdez 1720:17). Having satisfied all involved that this was a suitable location, the Mission San José y San Miguel de Aguayo was established (Valdéz 1720:32-35). The location of this first site is not recorded, but Fray Espinosa reported that it was located on the east side of the river, as is shown by Aguayo's map drawn shortly after its founding. The map does show the mission situated near the confluence of San Pedro Creek. The mission was moved to a new site on the west bank of the river prior to 1727 , but an acequia was apparently also constructed for the first location. If this is the case, where would this acequia have been?

Research indicates that the first site was later selected as the location for Mission Nuestra Señora de la Purísima Concepción de Acuña, and that the Pajalache, or Concepción, acequia was initially constructed to serve San José at its founding location. The Aguayo map clearly places the mission in this vicinity and archaeological investigations on the site have yielded ceramic evidence of occupation prior to 1730 (Scurlock and Fox 1977:51). The Pajalache acequia has traditionally been accepted as one of the oldest of the acequias. The first person who studied the history of the acequias, William Corner, stated that testimony from an 1858 trial established the date of construction as 1729 (Corner 1890:43). However, a review of the court case does not contain this date within the trial records, but states that the privilege to establish the acequia was granted “. . . previous to the foundation of the Alamo Church . . " (Rhodes v. Whitehead, et al. 1903). Regardless of how this is interpreted, it establishes that the acequia was begun before the occupation by Concepcion by at least three years. 
The Concepción, or Pajalache, acequia, as previously conjectured, may have been begun well before the new mission. The channel began on the east side of the river at a large dam that spanned a point just above the town's major ford at Presa Street. Because the entry point was at La Villita (the little village), one of the highest points in the downtown area, it required a massive cut to initiate a downward flow. The Concepción acequia was always noted as the largest of the ditches, so large in fact that it was reported that the mission fathers kept a boat on it to attend to its cleaning. It was certainly large enough at the inlet point, for the width was reported as $20 \mathrm{ft}$ (Corner 1890:44).

The acequia progressed southward along the east side of the road to the lower missions, to a point $2,500 \mathrm{ft}$ from the intake to where a canoe, or hollow $\log$, transported a later extension of the Alamo Madre over the canal on its return to the river. This was later replaced, probably during the mid-1800s, by a "substantial arched stone aqueduct" still extant in 1890 (Corner 1890:43-44). It then progressed along the road to the mission compound where it diverted westward to return to the river south of the confluence of San Pedro Creek. The original acequia had a total length of approximately 3.5 miles. In later times a double gate was installed 1.4 miles from the intake and an eastern branch was constructed to irrigate additional farm lands, adding another two miles to its length. Before the acequia was abandoned it encompassed over 10 miles of ditches.

On March 26, 1865, a huge cloudburst struck the city and filled the river and creek to overflowing. The river rose to a height of $14 \mathrm{ft}$ above normal, spreading from its banks throughout the downtown area. The residence of Jacob Waelder, on St. Mary's Street, was demolished by the force of the deluge and his wife swept away to her death. The flood left hundreds homeless, devastated the entire business section, and caused losses in the thousands of dollars.

In the aftermath of this disaster, the first major flood in over a decade and the worst in memory of the residents, Council took immediate action "to repair the bridges, replace them where necessary, and repair and clear the ditches without delay" (City Council Minutes [CCM] Office of the City Clerk, City Hall, San Antonio, C:475-476). They also appointed a special committee, consisting of

Captains F. Giraud and G. Scheicher and Mr. Considerant to ascertain and investigate various encroachments upon the river and other impediments, to what extent the rise of the river is owning to the existence of the same; what steps ought to be taken in the premises and whether or not a widening of the San Pedro Creek, within certain limits of the city, would be advisable [CCM, C:475-476].

The flood water also swept away the San José acequia dam, causing the old channel to be abandoned. The committee report stated that the primary causes, in their opinion, were "water walls built into and along the river and creek, the insufficiency of the openings of the bridges, and the stone dam built across the present head of the Concepcion ditch" (CCM, C:475-476). The necessary corrections-remove the obstructions from the channel-were rather obvious; however, the question of removing the dam was recognized by the committee as a delicate problem involving the property rights of many individuals of the community.

This was not the first time this problem had arisen. As early as 1828 the dam was recognized as a major obstruction in the river, but because of the rights of the land owners to irrigate their fields the problem had gone unresolved. The present committee was well aware of the public sentiment toward the loss of irrigation to the fields below the city; therefore, they took special care to establish the necessity of removing the dam, and also proposed solutions to appease the landholders. They stated ". . . it is our deliberate opinion that it should be removed. It requires no argument to show an ordinary understanding that a high and strong stone dam across a river is a serious obstruction, but to understand clearly how it affects the river at a time of a rise, perhaps a short explanation may not be out of place" (CCM, 
C:475-476). They then addressed not only the problem of the obstruction to the flow, but also the result of the filling of the river bottom through the action of silt accumulation and the resultant increase in flooding potential. "The city should ascertain the rights of owners of Concepcion lands to water for irrigation; and if such a right exists, and for the sake of the safety of the city, their present ditch is laid dry, the city should furnish them their amount of water from another channel. We will point out how this can be done" (CCM, C:475-476).

The committee then proposed the same solution that had been offered in 1828: to divert the flow of the Alamo ditch near its terminus into the Concepcion ditch to supply the land further to the south. They then proposed an entirely new solution to the problem.

A sufficient amount of water can be taken out of the river at the upper dam to supply three ditches as well as one of them, instead of following the Alamo ditch, if another ditch were made from where the Alamo ditch opens into the flat above Alamo City, taking in a large part of the ground between Alamo City and the foot of the Powderhouse Hill, a large scope of property, now comparatively worthless, could be supplied with water facilities and increased in value to a very great extent, and this new ditch could receive sufficient capacity to supply the Concepcion ditch [CCM, C:475-476].

Early in 1869 the way was finally cleared for the removal of the Concepcion dam. Earlier when this action was proposed, it had resulted in a court case that had eventually reached the State Supreme Court (Rhodes v. Whitehead 1903). Once this impediment was cleared, the city took action to remove the old structure that had so long been the reputed cause of so much damage by flooding (CCM, C:683). However, this did not end the problems with the old waterway, for the open channel continued to generate complaints.
The ditch is left open beside a public thoroughfare-the earth thrown out and the ditch together occupy two-thirds of the street, of course this condition of the street decreases the value of the property fronting thereon, and its continuance lay the city or county liable to the owners of the property in damages. Besides this, the ditch is twenty feet deep in places-during the rains often containing fifteen feet of water-makes it exceedingly dangerous. Only a short time since a cart, mule and man were hurled into this trap from the crossing leading from Guenther's Mill, the man miraculously escaping death [San Antonio Express, 16 February 1869].

The removal of the dam also created another problem for the city, one that had been recognized since its removal had first been proposed: the continued requirement to supply the land owner below the city with their authorized share of water for irrigation. The city engineer met this challenge by diverting the waters of the Alamo acequia, from the point of the aqueduct crossing the now dry ditch, to a new channel on the eastern margin of Garden Street (now South St. Mary's) (Corner 1890:44). The new ditch was required because this diversion produced a greatly reduced flow and consequently required a small channel. Although the dam for the Concepcion ditch had been breached in December, a major portion of the stone remained below water level and still served to impede the free flow of the river. In March the mayor requested a legal opinion on the final removal of the structure. The city attorney, T. S. Harrison, ruled "not only have the city authorities the power to remove said dam, but it is their duty to do so is as much as the Supreme Court of the State of Texas has declared the same to be a public nuisance" (CCM, D:1). The mayor was immediately authorized to remove this last barrier to the river. 


\section{RESULTS OF THE ARCHIVAL SEARCH}

From the description given by William Corner, coupled with the frequently reported width of the Concepción acequia, it is evident that just prior to the turn of the century the aqueduct was a substantive structure. It would have been constructed at street level to convey the small Alamo channel across the large Concepción ditch, which was frequently reported to have a width of approximately $20 \mathrm{ft}$; therefore, it may well have resembled the sole existing aqueduct near Mission Espada. Since the ditch was filled in ca. 1870 , there would have been no need to remove the last traces of the stone and, in all probability, the remains of the structure exist beneath the present street.

All the early records indicate that the crossing of the two acequias was located immediately to the north of the intersection of South Alamo and St. Mary's streets, but the exact location is more difficult to substantiate. The earliest known map indicating the location (Figure 2) is found among the G. Freisleben survey of property in the immediate area of the crossing (Freisleben Papers, Section Number 12:291/2, 17:34, City Mapping Section, Main Plaza Building). Although these papers are undated, they were acquired from his heirs by the city in 1888 , and consist of the papers of both G. Freisleben, the father, and G. Freisleben, the son, city surveyors and engineers for several years. The father served with the city from ca. 1852 until 1870; the map in question was drawn sometime during his tenure, since it was surveyed prior to the diversion of the Alamo acequia in 1870 .

The Koch bird's-eye view of the city of 1873 shows the new path of the Alamo acequia on the east side of St. Mary's Street, then called Garden Street, but it also indicates a branch of the acequia was open on the western margin of the street. This branch served to furnish water to the property owners between the ditch and the river below the King William district and was still being conducted across the street by the old aqueduct. The Sanborn Insurance map of 1892 indicates that this branch was still open at that time. However, by 1896 the western branch had been discontinued and the location of the aqueduct is no longer indicated.

\section{CONCLUSIONS AND RECOMMENDATIONS}

The records indicate a strong possibility that some of the stonework of the aqueduct may still exist beneath the street in the vicinity of where the water mains are to be installed. The preliminary planning called for the installation of mains $100 \mathrm{ft}$ either side of the center line of South Alamo Street to as far as Cedar Street. Measurements taken from the various maps indicate that the aqueduct is located $110 \mathrm{ft}$ from the center line of South Alamo Street, along the eastern edge of South St. Mary's Street. Considering the imprecise nature of the research material available for location, this falls uncomfortably close to the location of this historic structure. The Freisleben surveys also indicate that the western branch of the Alamo acequia may exist beneath the street some $60 \mathrm{ft}$ southwest of the intersection where it crossed South Alamo Street between St. Mary's and Cedar streets.

Due to the historic nature of both the aqueduct and the acequia, we recommend that all construction in the area of both of these buried resources be monitored during any excavation. In the event that any traces of either are encountered, the city should be prepared to curtail all further construction until they can be documented and, if necessary, extensive archaeological investigations can be conducted. 
<smiles>C1=[V]C[SiH2]1</smiles> 


\section{REFERENCES CITED}

Corner, W.

1890 San Antonio de Bexar: A Guide and History. Bainbridge and Corner, San Antonio.

Habig, M.

1968 The Alamo Chain of Missions: A History of San Antonio's Five Old Missions. Franciscan Herald Press, Chicago.

Rhodes v. Whitehead, et al.

1903 Report of Cases Argued and Decided in the Supreme Court of the State of Texas during the latter part of Tyler Session 1863, Austin 1863, Galveston, Tyler and Austin 1864, and Galveston Session 1865. Volume XXVII. 27 Texas 304. West Publishing St. Paul, Minnesota.
San Antonio Express

1869 The Old Ditch. 16 February.

Scurlock, D., and D. E. Fox

1977 An Archeological Investigation of Mission Concepcion, San Antonio, Texas. Texas Historical Commission, Office of the State Archeologist. Report 28, Austin.

Valdéz, J.

1720 Report of Captain Juan Valdéz, March 13, 1721. In The San José Papers, Part I: 1719-1791, Fr. B. Leutenegger, translator, Fr. M. A. Habig, compiler and annotator. Old Spanish Missions Historical Research Library, San Antonio, Texas. 
